\title{
Perennial grain crops in the West Soudanian Savanna of Mali: perspectives from agroecology and gendered spaces
}

\author{
Paul Rogé, Tidiane Diarisso, Fatoumata Diallo, Youssouf Boiré, Diakaridia \\ Goïta, Brad Peter, Moussa Macalou, Eva Weltzien \& Sieglinde Snapp
}

To cite this article: Paul Rogé , Tidiane Diarisso, Fatoumata Diallo, Youssouf Boiré, Diakaridia Goïta, Brad Peter, Moussa Macalou, Eva Weltzien \& Sieglinde Snapp (2017): Perennial grain crops in the West Soudanian Savanna of Mali: perspectives from agroecology and gendered spaces, International Journal of Agricultural Sustainability, DOI: 10.1080/14735903.2017.1372850

To link to this article: http://dx.doi.org/10.1080/14735903.2017.1372850

Published online: 06 Sep 2017.

Submit your article to this journal

View related articles

View Crossmark data $\nearrow$ 


\title{
Perennial grain crops in the West Soudanian Savanna of Mali: perspectives from agroecology and gendered spaces
}

\author{
Paul Rogé (D) $^{a}$, Tidiane Diarisso ${ }^{b}$, Fatoumata Diallo ${ }^{b}$, Youssouf Boiréc, Diakaridia Goïta ${ }^{c}$, Brad Peter ${ }^{d}$, \\ Moussa Macalou ${ }^{b}$, Eva Weltzien ${ }^{c}$ and Sieglinde Snapp ${ }^{d, e}$ \\ ${ }^{a}$ Department of Environmental Science, Policy, \& Management, UC Berkeley, Berkeley, CA, USA; ${ }^{b}$ Institut d'Economie Rurale (IER) \\ - ECOFIL, Bamako, Mali; 'International Crops Research Institute for the Semi-Arid Tropics (ICRISAT), Bamako, Mali; ${ }^{d}$ Center for \\ Global Change \& Earth Observations, Michigan State University, East Lansing, MI, USA; ${ }^{\mathrm{e} D e p a r t m e n t ~ o f ~ P l a n t, ~ S o i l ~ \& ~ M i c r o b i a l ~}$ \\ Sciences, Michigan State University, East Lansing, MI, USA
}

\begin{abstract}
Perennial grain crops may play an important role in environmentally sound and socially just food systems for Africa. We study the future possibility of integrating perennial grains into Malian farming systems from the perspective of agroecology, and more specifically using a gendered space approach. We interviewed 72 farmers across the sorghum-growing region of Mali. We found that perennial grains offer a vision for transforming human relations with nature that mirrors the resource sharing of customary land tenure, including patterns of extensive and intensive land use in time and space. Women interviewees identified a broad set of potential advantages and challenges to perennial grain production. Advantages include reduced labour, saving seed, and improving food security. Women farmers were concerned about livestock, water access, and resource limitations. We argue that perennial grains may increase access to land and natural resources for women farmers. Perennial grains may improve soil quality, reduce labour early in the rainy season, and provision more resources from fallow lands. Pastoralists stand to benefit from improved pastures in the dry season. We conclude that investments are needed to develop viable crop types in consideration of the complexity of West African farming systems and the local needs of women farmers and pastoralists.
\end{abstract}

\section{KEYWORDS}

Africa; agroecology; gender; Mali; perennial grains

\section{Introduction}

Arguments for sustainable farming systems rooted in perennial grains are well established (see Armstrong, Glover, Reganold, \& Cox, 2010; Cox et al., 2002; Cox, Glover, Tassel, Cox, \& DeHaan, 2006; Cox, Picone, \& Jackson, 2004; Crews \& DeHaan, 2015; Glover, 2005; Jackson, 1980; Jackson, 2002; Wagoner, 1990). The inspiration for developing an alternative to the standard of industrial agriculture by which human productive endeavours are measured is what Jackson of the Land Institute calls 'nature's standard', or perennial polycultures that mimic prairie ecosystems (Richards, 2009). Perennial plant communities are distinguished from annuals in their high resource availability and productivity while using resources efficiently and building soil quality (Culman, Snapp, Ollenburger, Basso, \& DeHaan, 2013). In comparison to annuals, perennial plant communities store more soil carbon, support a healthier soil microbial community, better maintain soil and water quality, increase nutrient use efficiency in the soil, and produce more above and below-ground biomass (Armstrong et al., 2010; Cox et al., 2006).

The ongoing scientific and intellectual contributions for perennial grain systems have thus far been openly shared, which makes them available to 'recombine with other forms of life, other ecologies, and other systems of knowledge production' (Johnson \& Goldstein, 2015). A common approach to developing novel perennial germplasm is 
through wide-crosses between annual crops and perennial relatives to confer perennial traits and allow for multiple harvests. Noteworthy examples include perennial wheat that was pioneered by plant breeders in Russia beginning in the 1930s, whereas perennial sorghum is a recent development (Cox et al., 2006).

This novel germplasm builds on indigenous farmer knowledge about mixed cropping and ratooned annuals, yet almost no research has been conducted to demonstrate how perennial grains might integrate into current food systems. Contextualization of the potential farmer demand for perennial grains is urgently needed. One of the few studies that interviewed farmers in the United States about their use of perennial wheat found that grain yield comparisons were less important to them than the ability to solve problems not addressed by their other crops (Adebiyi, Schmitt Olabisi, \& Snapp, 2015).

Emerging questions regarding the possible fit of perennial grains is particularly of interest in West Africa where there is tremendous pressure to close the yield gap between the genetic potential of modern crops and realized grain yields (see Hounkonnou et al., 2012; Larder, 2015; Struik, Kuyper, Brussaard, \& Leeuwis, 2014; Tittonell \& Giller, 2013). Perennial grains represent a transformative approach to improving soil fertility while providing high quality food and livestock forage (Glover et al., 2010).

We make the case for perennial grains as an achievable and sustainable option for West Africa based on empirical evidence from sorghum-producing regions of Mali. ${ }^{1}$ We interpret sustainability as environmentally sound food production that takes into consideration distributive and procedural justice (see Loos et al., 2014). This begins with a review of the literature on the historical uses of perennial grains in Africa and on the socio-ecological dimensions of West African agriculture and pastoralism. We also reflect on semistructured interviews with farmers in the sorghumgrowing region of Mali. We argue that the soil improving and forage potential of perennial grain systems will likely benefit women farmers and pastoralists, two groups that are often marginalized by the development of cash crops and intensified agriculture (Grigsby, 1996; Wooten, 2003). Contextualizing perennial grains within social and ecological contexts can help guide ongoing research and development efforts. Our analysis is also relevant to scholarly debates around perennial grains as a pathway to transform food systems.

\section{Historical precedence in Africa}

The concept of sustainable food systems rooted in perennial grains is not only a hypothetical future scenario in the African context. Over 60 wild grasses from mixed annual and perennial grasslands have been harvested in Africa for grain (NRC, 1996, p. 1:251; Harlan, 1989). Some of these species include guinea millet (Brachiaria deflexa) with a domesticated race in Guinea, Egyptian grass (Dactyloctenium aegyptium), and several species of fonio (Digitaria spp., Harlan, 1989, pp. 86-87; Dalziel, 1985; Schnell, 1957). The seed of Saharan grasses contain about twice as much protein as domesticated cereals (17-21\%, NRC, 1996, p. 1:257; Busson, 1965). Wild grasses span the spectrum from survival foods during times of scarcity to staple foods (Harlan, 1989, p. 80).

Wild grasslands offer an example of how crops can produce grain and forage resources that are similar to annual dual purpose crops but growing under more marginal, unfavourable conditions, and with less labour inputs. Kreb or kasha is a mix of several grass species that range from Bornu in Nigeria to Darfur in Sudan (Harlan, 1989, pp. 86-87). Several perennial species related to teff (Eragrostis spp.) are important in the kreb complex, including E. cilianensis, E. ciliaris, E. gangetica, E. pilosa, and E. tremula (Dalziel, 1985; Harlan, 1989, pp. 86-87). Kreb grasslands protect soils from desertification and overgrazing; the annual species in the kreb complex are fast growing and produce abundant seed while the perennial species protect soils due to their longer period of growth (Batello, Marzot, Touré, \& Kenmore, 2004, pp. 108113). The environmental conditions where kreb grows are unfavourable for domesticated crops, replete with grain-eating birds such as Quelea quelea and soils that are saline, infertile, or waterlogged (Batello et al., 2004, pp. 108-113).

The use of kreb has become sporadic as public policy has encouraged the settling of nomadic herders, who traditionally would set aside areas from animal grazing until after grains were harvested (Batello et al., 2004, pp. 106-107). In addition to the breakdown in traditional authority to enforce setasides, the localized grazing that has become more commonplace does not allow for grains to form (NRC, 1996, p. 1:253). For centuries, kreb was a staple crop for local consumption as well as for sale. There 
existed an expansive trade of kreb among tribes (Denham, 1985; Harlan, 1989, pp. 86-87; Nachtigal, 1971). The value of kreb fluctuated from half the price of wheat to double the price of millet (Batello et al., 2004, p. 112). Also, kreb was occasionally collected from ant and termite nests in cases of extreme hardship (Batello et al., 2004, pp. 108-113).

In addition to multi-use perennial grasslands, some farmers in Africa ratoon annual crops to extend their production. Ratooning is the cultural practice of cutting crops near their crown after a first harvest of grain or animal fodder. This permits the crops to grow back to produce subsequent harvests (NRC, 1996, pp. 1:127-129). For example, colonial administrators in the territory known today as Zambia observed that perennial sorghum, likely a ratooned annual, was broadcast sown in mixed crop gardens (Moore \& Vaughan, 1994, pp. 37-39). One crop rotation of shifting cultivation gardens (citemene) included perennial sorghum. In the first year, millet was sown with sorghum. Groundnuts, or peanuts, were planted among the regrowing perennial sorghum in the subsequent year. Perennial sorghum was grown as a sole crop in the third year. In the fourth year, beans were planted on mounds (mputa, Moore \& Vaughan, 1994; Trapnell, 1953, p. 46). These historical examples point to the potential role that perennial grains may play in the future of farming systems in Africa and beyond.

\section{Agriculture and pastoralism in West Africa}

The West African Soudanian Savanna is characterized by a unimodal monsoon rainy season from April to October. Land and water resources customarily pass between agriculturalists in the rainy season and pastoralists in the dry season. Analytical frameworks often fail to adequately explain the complex rules of access and use of customary land tenure (Rocheleau \& Edmunds, 1997). Tenure 'niches' can describe the usufruct of the physical landscape as well as other cultural and religious spaces (Grigsby, 2004; Rocheleau \& Edmunds, 1997). Common property institutions mediate natural resource management, which offer numerous advantages over individualized tenure or property arrangements. These include less costly enforcement and monitoring, equitable distribution of subsistence within a village economy, more equitable spread of rights, as well as lower risks posed by environmental uncertainties (Grigsby, 1996; Runge, 1986).
In Mali, annual grains occupy $62 \%$ of arable lands, $85 \%$ of which are managed by family farms that represent approximately $65 \%$ of the total population (CEPIA, IER, \& CIRAD, 2008, p. 210). The Bambanan, or Bambara, are a settled agricultural people that historically organized by collective patrilineages called gwas (van Dusen Lewis, 1978). Collective production has in many cases been sustained in smaller multigenerational families called duw that organize around the authority of a senior male member (Wooten, 2003). Generally speaking, male heads of the gwas or duws are responsible for staple grains while individual families and women produce the accompanying foodstuffs. Women also use their own resources and harvests for feeding children extra meals (Van de Broek, 2009). The use of family labour is similarly governed by cultural rules, whereby women and younger men spend fixed hours and days working in the collective plots. The remaining time they spend in their own plots or on other tasks. Older women, especially widows, tend to spend more time in their individually managed plots. The gwas or duws are the first safety net for any individual, followed by the village. Husbands and co-wives generally manage their financial resources separately (Creevey, 1986; Creevey, 1987; Thiam, 1986), except in periods of hardship when men may request support from their wives.

Bush fallows are common in West Africa. They typically involve 3-5 years of cultivation followed by a longer fallow period on the order of 5-10 years, depending on rainfall (Grigsby, 1996; Grigsby, 2004). State policies and parastatal agencies have promoted cash cropping and synthetic fertilizer inputs, which in some cases diminishes the use of the bush fallow (Grigsby, 1996). Economic benefits from cash crops have benefited some farmers.

However, there is almost no recent literature that looks specifically at the relationship between changes in resource access and women's well-being. One study argued that a gender bias exists in accessing commercially viable resources for Bambanan rural societies based on a case study located $35 \mathrm{~km}$ from the capital city of Bamako (Wooten, 2003), and Boserup (1971) much earlier made the general observation that the majority of women have not experienced improvements in their well-being from commercial agriculture despite their significant contributions to farming in Africa. Moreover, the transition to cash crops affects women's access to important resources such as wild harvested plants and fuelwood 
from the fallow stage of a land-extensive production cycle (Grigsby, 1996).

Similarly, pastoralists have lost access to important natural resources due to demographic changes and modern efforts to transform West African farming systems. Monsoons create an approximate northsouth gradient of vegetative productivity, nutritive quality, and phenology (de Vries \& Djitèye, 1982; Le Houérou, 1989). The rainy season signals the movement of livestock northward ( $>16^{\circ}$ north latitude) to rangelands with high nutritional content (de Vries \& Djitèye, 1982). With the end of the rains the northern pastures senesce and livestock move southward along transhumance corridors. These long-established corridors link to coastal countries that highly value Sahelian meat (Thébaud \& Batterbury, 2001).

Multiple factors have destabilized pastoral communities (Batterbury \& Forsyth, 1999), including the expansion of agriculture that block access routes between pasture and water resources, thus reducing the whole system's viability (Brottem, Turner, Butt, \& Singh, 2014). Many conflicts in West Africa have their roots in arguments between farmers and pastoralists. At the same time, Mali has experienced a steep expansion of drylands to crop production on a national scale that has resulted in only minor yield increases and dramatically reduced land available for fallowing and pastoralism.

The reciprocal relationship where pastoralists would stable their animals on agricultural fields in the dry season had existed prior to the late 1960s, but is now less common since farmers tend to keep harvest residues for their own herds (Thébaud \& Batterbury, 2001), which may be in part an attempt by farmers to increase manure availability. Subsidized fertilizer inputs received for cash crops and maize also reduces the importance of animal manures. This has also contributed to diminishing the reach of the transhumance (Bassett \& Zuéli, 2000), as has the trucking of live animals.

Although the mixed agriculture and pastoral economy of Mali is integrated with local and more distant markets, agroindustry in general has received only modest investments (CEPIA, IER, \& CIRAD, 2008, p. 212). The Malian state has also implemented a politic of disengagement, liberalization, and privatization as part of joining the West African Monetary Zone (CEPIA, IER, \& CIRAD, 2007, p. 227).

\section{Materials and methods}

We used a case study approach due to its notable advantage of producing rich data for interpreting complex situations. A case study is an 'in-depth exploration from multiple perspectives of complexity and uniqueness of a particular project, policy, institution, programme, or system in a "real life" context' (Simons, 2009, p. 21). The merit of case studies rests in understanding the uniqueness of situations by referencing the particular (Bourdieu, 1992, pp. 233234) and identifying counterfactuals that question well-established perspectives (Feyerabend, 2010). Meaning from the qualitative analysis of case studies often emerges from the research results rather than being predefined (Svensson \& Doumas, 2013).

The subject, or historical unity (see Thomas, 2011), in this case study is the future possibility of perennial grains in the sorghum-producing region of Mali. Our interest in this subject originated from parallel research to test lines of perennial sorghum bred by the Land Institute in Salina, Kansas and currently undergoing field trials at the experiment station of the International Crops Research Institute for the Semi-Arid Tropics (ICRISAT) near Bamako, Mali. Our site selection was informed by prior knowledge from years of participatory plant breeding and variety selection with communities in the region.

We chose three study sites along a vegetation productivity gradient of the sorghum-producing region in Mali: the Cercles ${ }^{2}$ of Tominian, Dioila, and Bougouni (Figure 1). There is noticeable variability from north to south in terms of temperature, precipitation, soil quality as soil carbon, and vegetation productivity as net primary productivity. ${ }^{3}$ Tominian to the north is the warmest and driest Cercle. Between 2000 and 2014, Tominian experienced a mean temperature of $28.8^{\circ} \mathrm{C}$ and received a mean of $757 \mathrm{~mm}$ of precipitation over the May-October growing season (Table 1). Over the same period, Dioilla averaged $27.3^{\circ} \mathrm{C}$ with $862 \mathrm{~mm}$ of precipitation. Bougouni to the south had the lowest temperatures and highest precipitation levels of the three Cercles at $25.9^{\circ} \mathrm{C}$ and $982 \mathrm{~mm}$ respectively. The indicators that we use for soil quality and vegetation productivity both increase from Tominian in the north to Bougouni in the south.

Our case study is based on semi-structured interviews (following Bernard, 2011). An initial set of questions provided a flexible structure to guide conversations with farmers. We tested the questions near Bamako, Mali. However, the guiding questions continued to evolve as we conducted our study to incorporate informant feedback and unanticipated dimensions. We documented responses to follow-up and clarifying questions that emerged during the 


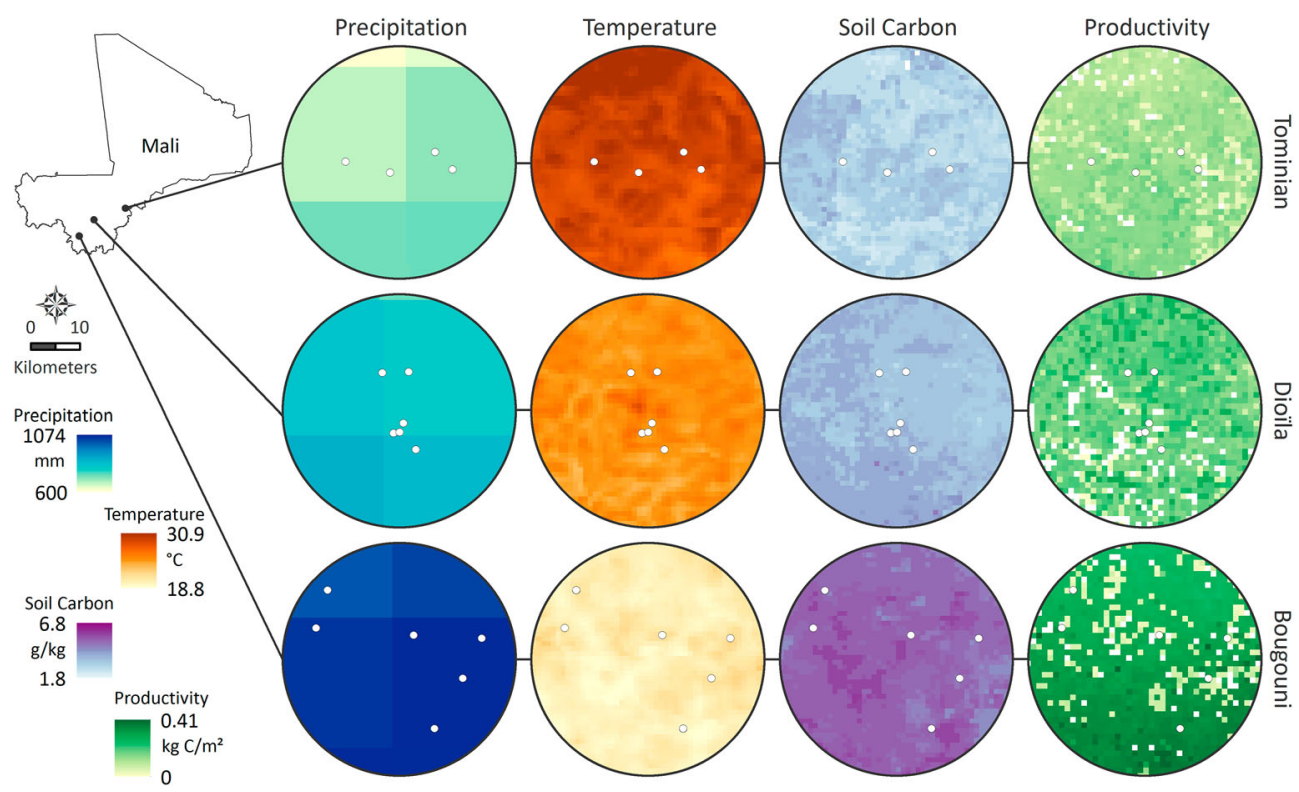

Figure 1. A map of the sample villages in the Cercles of Bougouni, Dioila, and Tominian in Mali. The map illustrates mean May-October temperature and precipitation, as well as mean soil carbon and mean annual vegetation productivity from 2000 to 2014 within each Cercle. We use grams carbon per kilogram soil as an indicator for soil quality and net primary productivity as an indicator for vegetation productivity. Data sources: precipitation from GSFC DAAC (2011), temperatures from LP DAAC (2000a), soil carbon from ISRIC (2013), and net primary productivity from LP DAAC (2000b).

interviews. In March 2015, we interviewed 24 farmers per Cercle for a total of 72 interviews. Two male and two female farmers in each of the six villages per Cercle that we visited were interviewed.

Each interview was with a member of a different agricultural exploitation, to use the language of the World Bank (exploitation agricole, CEPIA, IER, \& CIRAD, 2007). However, we make reference to them as multi-household family farms, or simply farms (following Djurfeldt, 1996). The size classification of family farms that interviewees proposed for the community was coherent with how they classified their own farms both in numbers of individuals and households (ménages). Seventy-seven per cent of the interviewees from Bougouni and Dioïla self-identified as belonging to medium-sized farms, which corresponds to approximately 25 individuals across 5 households. In Tominian, $85 \%$ of interviewees identified as belonging to medium farms ( 15 individuals across 9 households) or to small farms (10 individuals across 2 households). It should be noted that interviewees in Tominian were of the Bobo ethnicity, which required us to recruit local translators who spoke both the Bambara and Bobo languages.

The object, or analytical frame for interpreting our subject (see Thomas, 2011), is agroecology, which is a transdisciplinary, participatory, and action-oriented field of study (Méndez, Bacon, \& Cohen, 2013) that strives for sustainable food systems based on local farming and scientific knowledge. As eloquently articulated by members of movements for food sovereignty (Nyéléni Declaration, 2015)

Table 1. Mean May-October temperature and precipitation, as well as mean soil carbon and mean annual vegetation productivity from 2000 to 2014 within each Cercle of Bougouni, Dioïla, and Tominian in Mali.

\begin{tabular}{lcccc}
\hline Cercle & Temperature $(C)$ & Precipitation $(\mathrm{mm})$ & Soil carbon $(\mathrm{g} \mathrm{C} / \mathrm{kg})$ & Productivity $\left(\mathrm{kg} \mathrm{C} / \mathrm{m}^{2}\right)$ \\
\hline Tominian & 28.8 & 757 & 2.9 & 0.106 \\
Dioïla & 27.3 & 862 & 3.5 & 0.141 \\
Bougouni & 25.9 & 982 & 4.3 & 0.174
\end{tabular}

Data sources: precipitation from GSFC DAAC (2011), temperatures from LP DAAC (2000a), soil carbon from ISRIC (2013), and net primary productivity from LP DAAC (2000b).

Note: We use grams carbon per kilogram soil to a depth of $200 \mathrm{~cm}$ as an indicator for soil quality and net primary productivity as an indicator for vegetation productivity. 
Our ancestral production systems have been developed over millennia, and during the past 30 to 40 years this has come to be called agroecology. Our agroecology includes successful practices and production, involves farmer-to-farmer and territorial processes, training schools, and we have developed sophisticated theoretical, technical and political constructions.

Our specific analytical focus is a gendered space approach that aims to 'uncover, recognize and reinforce those spaces in the rural landscape in which women exert relatively more control over resource management decisions and from which they are more likely to derive benefit' (Rocheleau \& Edmunds, 1997). Male and female interviewees described the plots that they directly managed in the previous year, which allowed us to characterize the shifting and complex usufruct of arable land during the rainy season. Plots that male interviewees managed in 2014 we call male plots and those that female interviewees managed we call female plots. Access shifts seasonally and therefore these are dynamic categories.

We characterized the family farms by exploring how farmers of both genders matched their grain crops to available plots of land during the 2014 rainy season. We suspected that perennial grains might have the best potential to grow under specific field conditions, such as in soils that retained soil moisture in the dry season or specific agroenvironments. We asked farmers to place pieces of paper representing the plots that they managed in relation to their homestead. Farmers compared their plots in terms of soil fertility and soil moisture. Interviewees ranked the plots in order of general preference, as well as in terms of soil moisture and fertility. We converted each interviewee's ranking into a binary response. Plots were also mapped to their crops. The participatory exercise of identifying plots with pieces of paper served as a reference throughout each interview.

We also asked farmers questions about their choice of crops and varieties that encompassed uses such as sale and family consumption. We were particularly interested in farmers' perceptions of short-, medium, and long-duration varieties in relation to planting and harvesting dates. Finally, we asked questions about cultural practices, such as ratooning and water conservation strategies that are associated with crops whose cycle extend into the dry season. Plots dedicated to fruit production and horticulture were excluded since the focus of our study is on grain crops. We analysed the information from our field notes using various $\mathrm{R}$ packages (Neuwirth, 2011; R Core Team, 2013; Wickham, 2007; Wickham, 2009; Wickham, 2011). The regional map in Figure 1 was created with ArcMap (ESRI, 2014) and the conceptual schematic in Figure 2 with Inkscape (2015).

\section{Results}

\section{A gendered view of land use}

Women play a critical role in restoring soil fertility on dryland plots during the rainy season even though men of the farm make decisions about crop rotations (Figure 2). The allocation of dryland plots to individuals within the farm is made by a male elder (chef de famille) following patrilineal inheritance. The most fertile drylands are managed by men. We propose the conceptual model depicted in Figure 2 to understand gendered land access.

Women are allocated the less fertile dryland plots through their husbands or the male farm managers (chef de travaux) at the beginning of the growing season, depending on crop rotations on male plots. This allocation of female plots might not occur until after male plots are sown, and there is weak tenure security from year-to-year. Crop rotations are practiced on both male and female plots, however we cannot report on a frequency of rotation. Importantly, women in the three Cercles sow nitrogen-fixing legumes on $40 \%$ of plots while men sow them on $26 \%$ of plots. Female plots often include intercrops and rotations with legumes such as cowpea or groundnut and cereals that tolerate poor soils such as fonio or sorghum.

When farmers notice a decrease in crop productivity, they rest dryland plots in fallows for 3-5 years. Unplanned fallows also occur occasionally due to labour, financial, or health problems. Male interviewees in Bougouni and Dioïla mentioned not fallowing because of prohibitively small landholdings. In contrast, for women decisions not to fallow may be due to limited access to more fertile lands.

In Bougouni and Dioilla, women also cultivate seasonally flooded lowlands for rice and fonio production. Women gain access to flooded lowlands through their stepmother, either by working together on the land or bequeathing it if the stepmother is unable to work them.

Migratory pastoralists and local herders have usufruct to free range livestock during the dry season. Livestock are sometimes corralled to collect their 


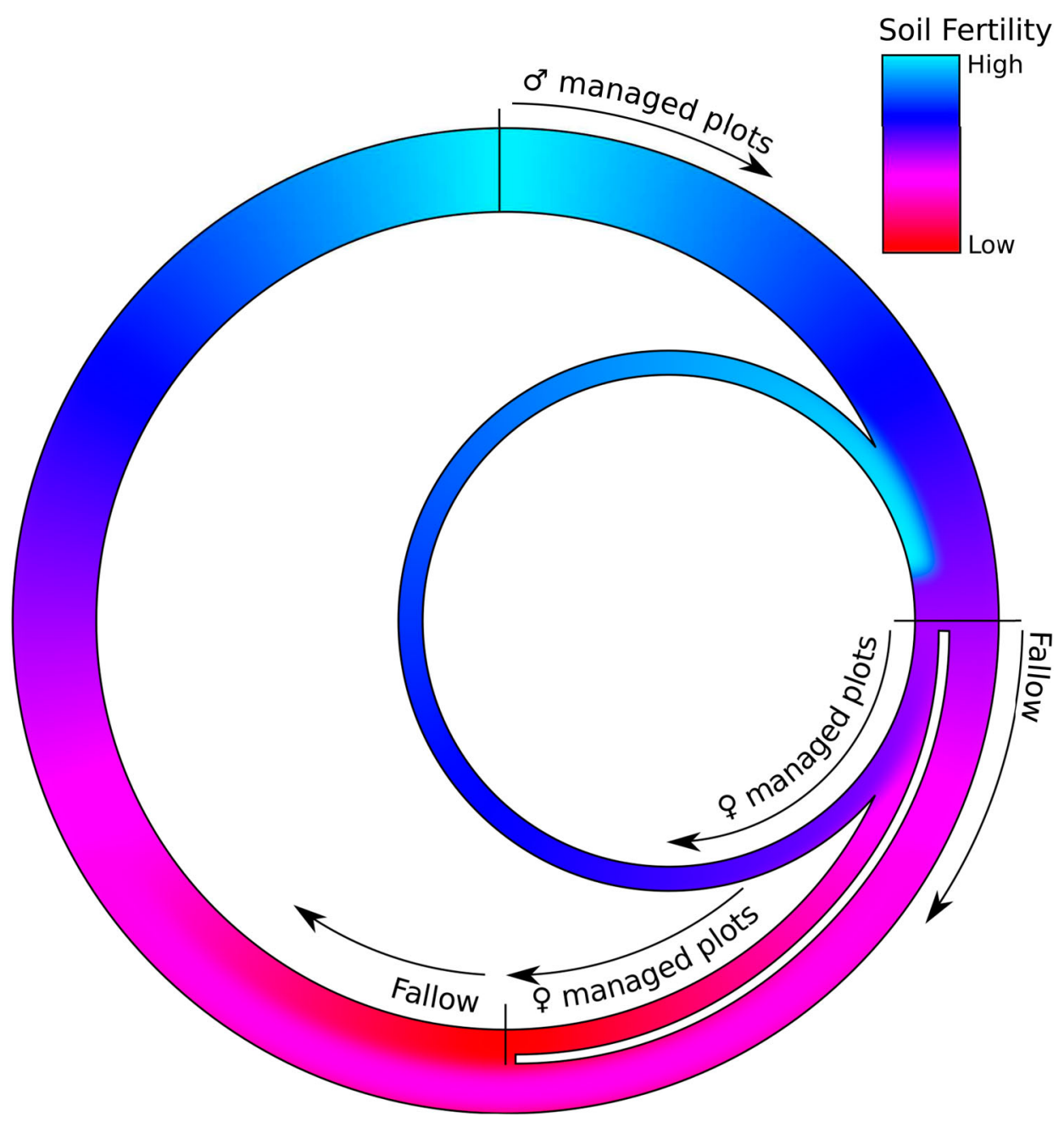

Figure 2. A conceptual schematic of the allocation and rotation of dryland plots during the rainy season based on soil fertility. ' 0 managed plots' are those that male interviewees manage and 'o managed plots' are those that female interviewees manage. We omit seasonally flooded lowlands and home garden plots. The proportions of the circle assigned to each land use are not scaled to time.

manure or they are parked in plots with access to water on the order of days to weeks. Farming families may provide food grain to herders who graze livestock on their plots. Livestock are corralled or are returned to their places of origin during the rainy season. However, according to farmers there is no social mechanism for compensation if their crops are damaged by livestock.

\section{The division of agricultural labour}

Women and youth (children and young adults) of the family farms contribute their labour across all plots whereas the large majority of men's labour goes to male plots (Figure 3). ${ }^{4}$ Across the Cercles, $95 \%$ of agricultural labour comes from within farms. Youth are the largest source of agricultural labour. Seventy-nine percent of labour is destined to male plots that are managed by men. This is due to the imbalance in land allocation between genders since labour per hectare is approximately equal for male and female plots. Soil cultivation is largely the domain of youth and men on all plots. Ninety-four percent of men's labour goes to male plots that they manage.

In contrast, two thirds of women's labour is destined to male plots. Women contribute to $28 \%$ of the labour for soil cultivation and $58 \%$ of the labour for remaining tasks on female plots. Men in Dioïla and Tominian make some contributions to soil cultivation on female plots. 


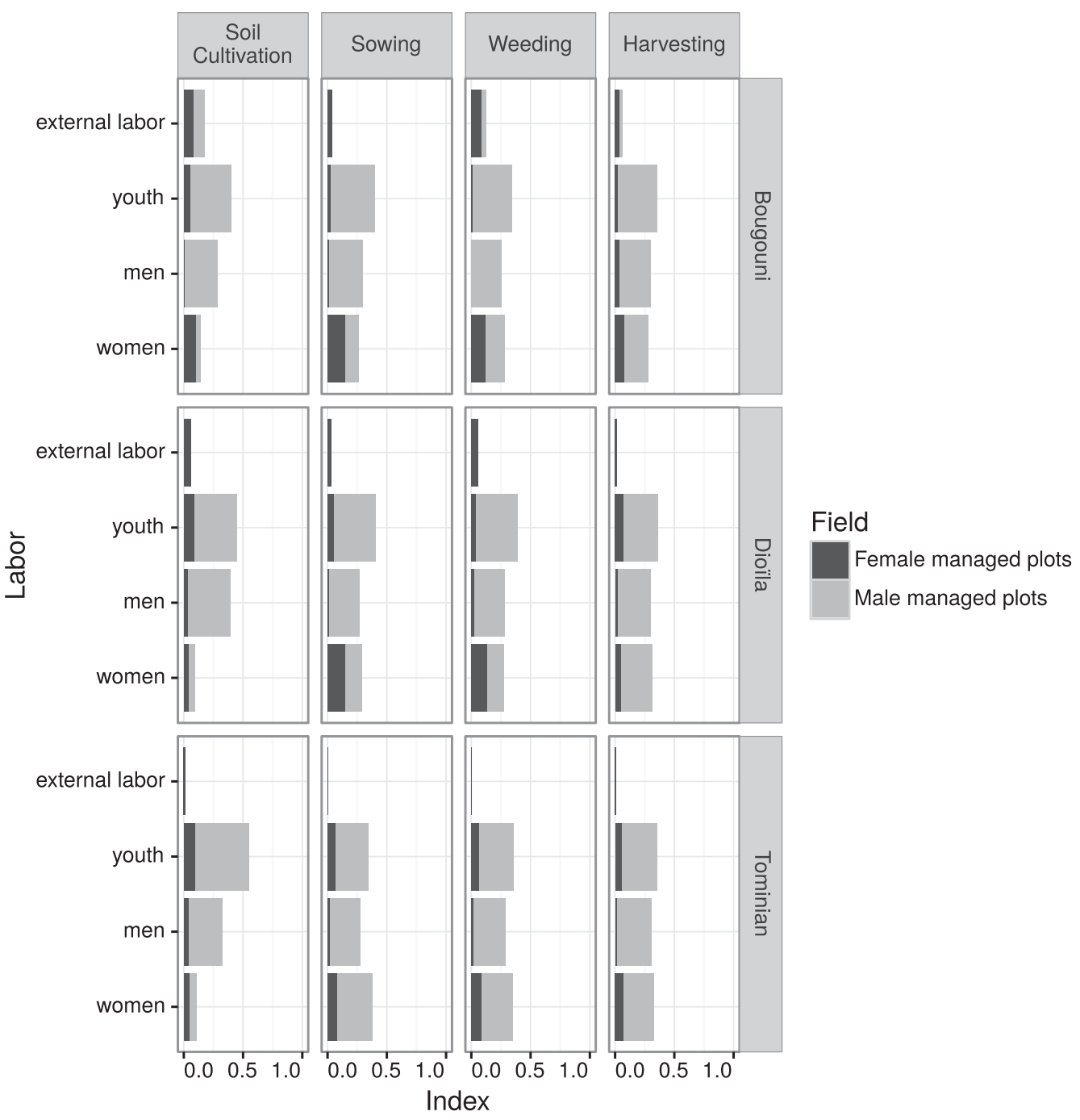

Figure 3. The overall labour contributions of individuals within the family farm - youth, men, and women - as well as external labour to the farm, for plots managed by men and women in each Cercle of Bougouni, Dioilla, and Tominian. The index of responses in each frame of the figure sums to a total value of one.

More external labour is used for female plots in Bougouni and Dioïla than in Tominian.

\section{The placement of crops and the choice of varieties}

Labour availability affects the sowing and harvest dates of field crops that farmers grow, which differs most by gender (Figure 4). Across all plots and regions the median sowing date is in June. However, sorghum and groundnut have earlier sowing dates in male plots than in female plots. This is also the case for maize in Bougouni and for fonio in Dioila and Tominian. In addition, plots managed by men have a wider range of sowing dates than female plots managed by women. This may explain why women plant what they consider to be 'short duration' varieties for $80 \%$ of their crops.

Cotton and rice are particularly gender-specific (Figure 5). Cotton is only grown on male plots. It is more commonly grown on preferred plots with greater soil moisture and fertility in both Bougouni and Dioila. In Bougouni and Tominian, rice is produced on less preferred male plots that are frequently ranked as of low fertility and of high moisture. Groundnut is produced by both genders, but is grown on plots that rank 


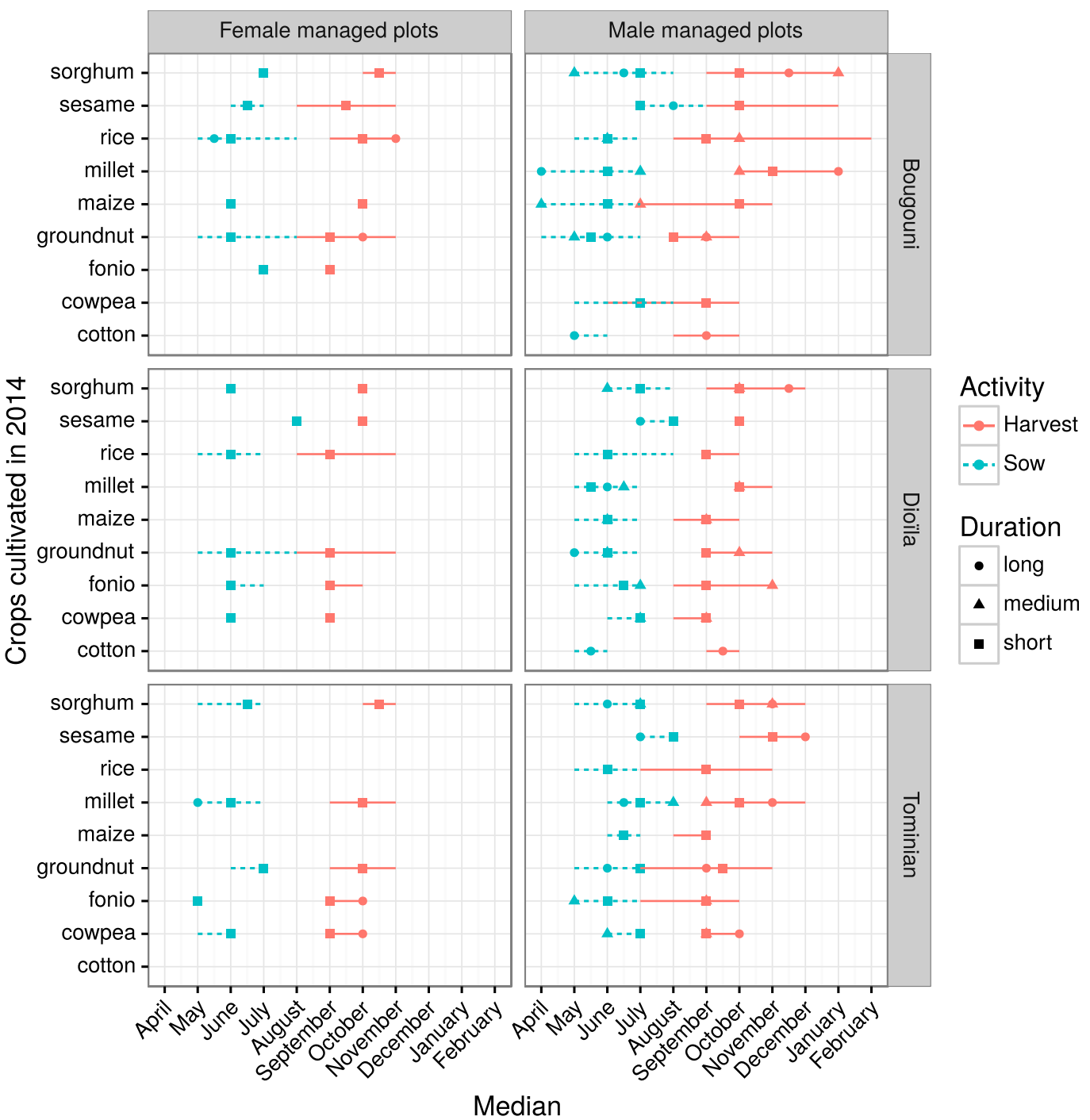

Figure 4. The median and range of sowing and harvest months in 2014 for long, medium, and short duration varieties of crops grown on male and female plots.

differently. Women in Bougouni and Dioïla plant groundnuts almost $50 \%$ of the time on moist, fertile and preferred plots whereas it is commonly produced by men on less humid, less fertile, and less preferred plots.

In contrast, women choose to produce groundnuts on plots that they prefer more, but that are still less humid and less fertile. However, the preference ranking differs by region; groundnuts are placed on preferred female plots close to $100 \%$ of the time in Bougouni, $50 \%$ of the time in Dioila, and $0 \%$ of the time in Tominian. Rice in the female plots of Bougouni and Dioïla are frequently placed in less preferred plots that rank high for soil moisture. They also are placed on female plots that rank as more fertile in Bougouni and less fertile in Dioila. No farmers in Tominian that we interviewed produce rice on female plots.

We report on the placement of the remaining crops by Cercle since little difference was reported between male and female plots (Figure 6). Sorghum, millet, and fonio tolerate poor soil quality and do not require organic or chemical fertilizers to achieve a good level of production. They are resistant to drought and witchweed (Striga spp.). One farmer narrated that the roots of sorghum are strong and draw water from deep in the ground to create moisture in the roots. 

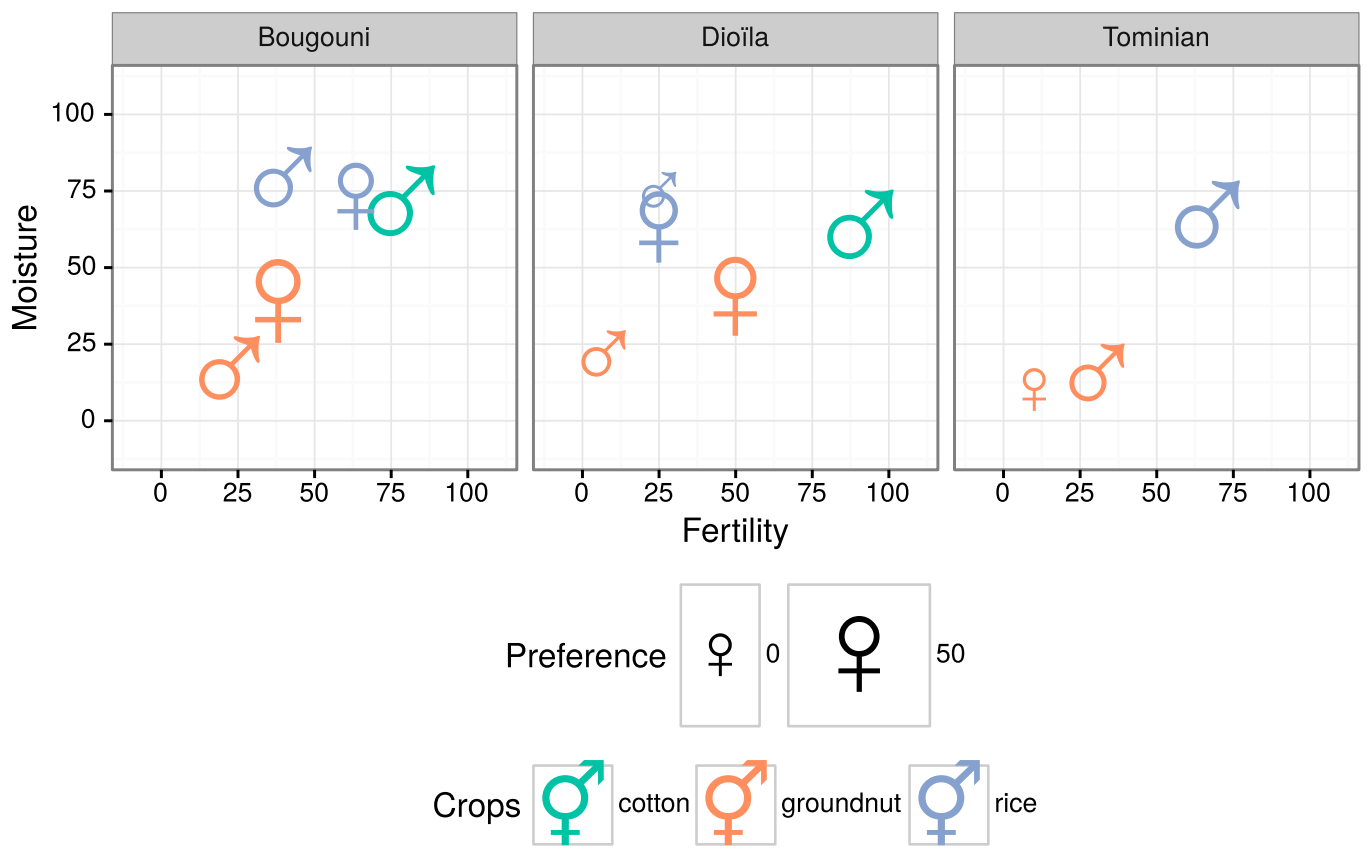

Figure 5. The percentage of times that cotton, groundnuts, and rice are placed on plots with high-soil moisture, high-soil fertility, and plots that farmers generally prefer. The responses are reported separately for plots managed by men ( $\left.{ }^{\alpha}\right)$ and women (o).

Even so, sorghum is frequently placed on preferred plots across all Cercles, most notably in Tominian. The plots where farmers in Bougouni and Dioïla grow sorghum varies in terms of soil fertility and moisture ranking. However, in Tominian farmers clearly produce sorghum on fertile plots that retain soil moisture. In contrast, maize is more often produced on preferred plots with higher levels of soil moisture and greater fertility in Bougouni and Dioila.

Fonio is produced on less preferred plots in Bougouni and Dioila and on a slightly greater number of preferred plots in Tominian. It is also cultivated on more plots that rank low in soil fertility and moisture in the three Cercles. The plots that produce millet in Bougouni and Dioïla are mixed in terms of all rankings. However in Tominian millet is produced on preferred plots with high fertility; soil moisture rankings are mixed. Cowpea and sesame are almost unanimously produced on less preferred plots with low fertility and soil moisture in the three Cercles.

\section{The use of grain crops}

Male plots in Bougouni are used for the market production of cotton, groundnuts, and maize. Similarly in Dioïla, male plots are used to produce cotton, peanut, and sesame for sale. These crops are also exchanged with neighbours for staple grains, such as maize and sorghum. The harvest from male plots of groundnuts and sesame in Tominian is partly sold to cover family expenses and to buy agricultural products. The situation is very similar on female plots where women sell half of all their crops and use the other half as food.

Periods of food shortages generally are the months of May - August. When shortages occur, families reduce their food consumption during the dry season when there is less agricultural work, sell animals to buy grain and feed their families, receive food aid, or seek assistance from family members to purchase supplemental sorghum. In times of hardship farmers rely on early maturing crops like maize and cassava, as well as sorghum, millet, fonio, and groundnut. In Dioïla, families rely on early maize, fonio, cowpea, and sorghum. In Tominian, farmers rely on fonio, millet, sorghum, and groundnut.

Farmers select earlier maturing varieties because of the unpredictable climatic conditions. Farmers in all three regions experience intense, erratic, and inadequate rainfall, as well as rainy seasons that are delayed or end early. A poor distribution of rainfall also causes drought conditions during the rainy 

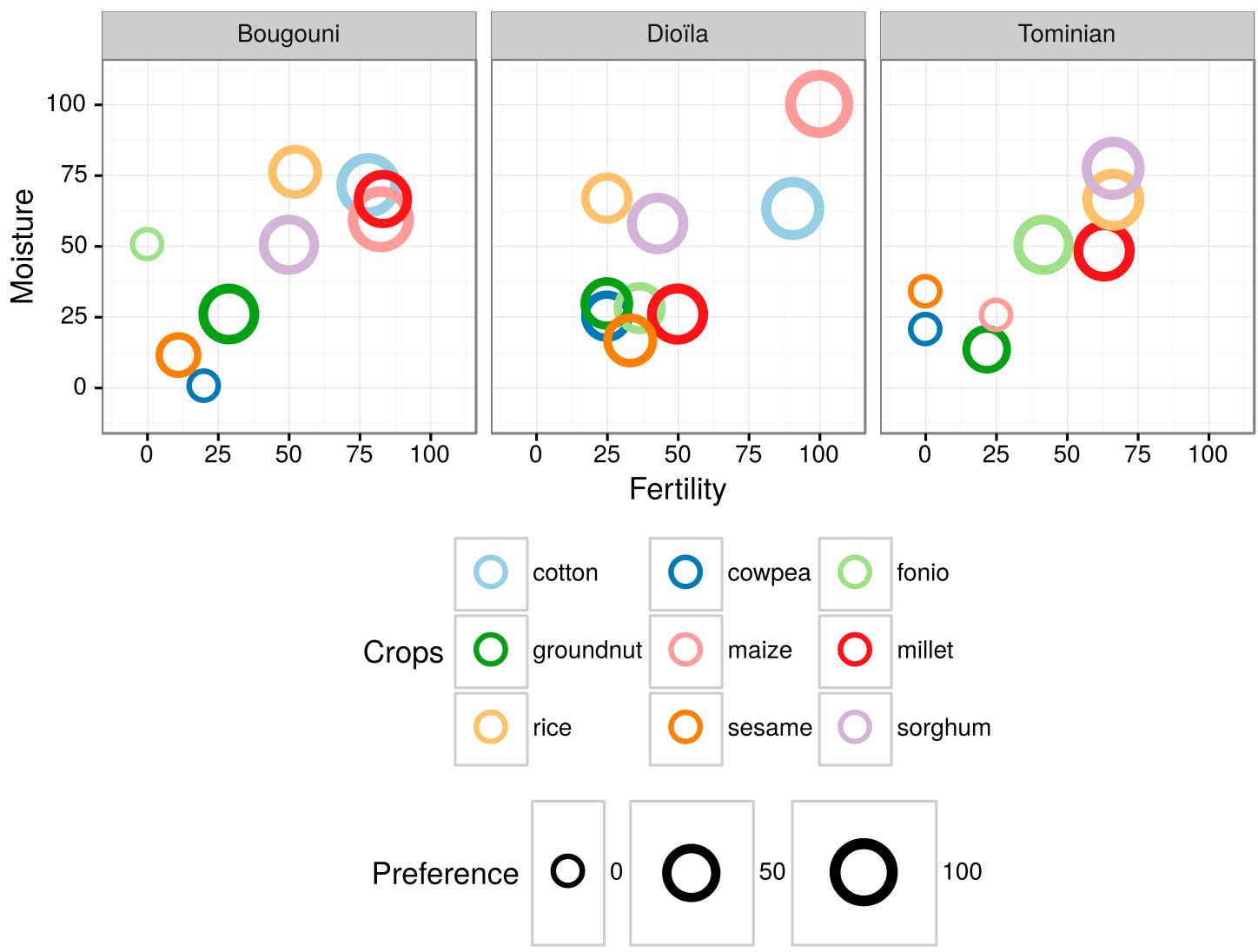

Figure 6. The percentage of times that crops are placed on plots with high-soil moisture, high-soil fertility, and plots that farmers generally prefer. The responses are combined across plots managed by men and women (O).

season. Strategies for adapting to the short rainy season have included the use of short-duration varieties, crop diversification, and planting drought resistant crops.

In past generations wild seeds were harvested during times of food shortage. In Bougouni, wild seed that resembled rice and a plant called bourgou were harvested. Women had harvested wild seeds in Dioilla. In Tominian, some farmers had harvested wild seeds of a plant called main that are similar but smaller than rice grains. Many other leaves of trees, wild tubers, bulbs, and fruits are harvested during times of shortage and also for pleasure and food diversity.

\section{A possible future}

Farmers communicated possible advantages and challenges to integrating perennial grain crops into their farming systems (Figure 7). Male farmers in the three Cercles view the reduction of labour as the primary advantage to a perennial grain crop, while crop damage by livestock during the dry season is the primary challenge. These are both important issues for women farmers, however their perceived advantages and challenges were more evenly spread across a host of issues. Advantages of perennial grain crops for women include reducing seed purchases and the amount of seed sown, as well as improving year-round food security. Other important challenges for women include limited water sources in the dry season and a lack of infrastructure for irrigation. Also, women face numerous resource limitations, such as a lack of human labour, insufficient financial means for buying fencing material, poor soil fertility, land access, and restricted access to animal manures. Differences between the Cercles are less noticeable (not shown).

Male and female interviewees in the three Cercles mentioned similar characteristics of plots that make them potentially suitable to produce a perennial grain crop. The primary characteristic is the ability of soils to retain moisture, which includes the following 


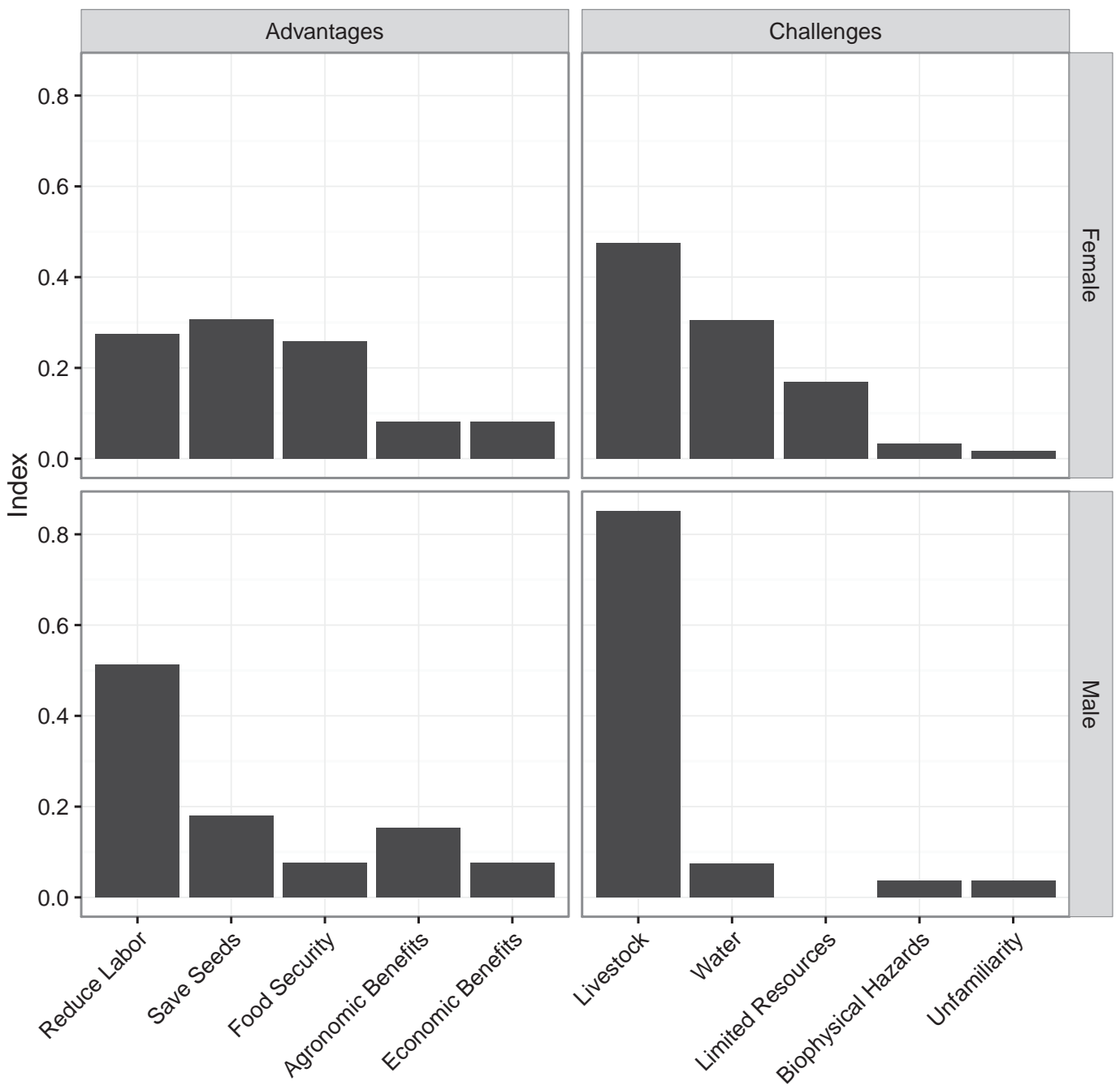

Factor

Figure 7. The potential advantages and challenges for perennial grain production as identified by male and female farmers in Mali. The index of responses in each frame of the figure sums to a total value of one.

elements: plots in the lowlands; plots with a silty loam soil texture; plots located at the base of hill slopes; and the proximity of plots to rivers. Moreover, the proximity of plots to homesteads might protect certain perennial grain crops that are sensitive to livestock damage.

Farmers across Cercles and gender reported that plots with the greatest capacity to retain soil moisture in the dry season are the seasonally flooded lowlands. Lowlands capture water in the rainy season, and thus retain soil moisture longer during the dry season or even year-round. Plots adjacent to the lowlands and down slope also conserve soil moisture such that rice production is possible in high rainfall years. In contrast, lowlands in Tominian only retain soil moisture for approximately 1-2 week following rainfall events.

Deep soils with high clay and silt content retain soil moisture in the dry season. In Dioïla, rainwater better infiltrates clay loam and sandy loam soils, which allows some varieties of sorghum to regrow in midMarch. However, similarly described soils in Tominian retain soil moisture for only a short period of the dry season. For some farms in Tominian, none of their plots retain moisture because of the sandy soil type. Few interviewees described the effect of perennial vegetation on soil moisture. For example, only one interviewee in Bougouni attributed the conservation 
of soil moisture to the shade provided by trees within plots.

Soil moisture on male plots is conserved during the dry season and the beginning of the rainy season by applying organic manure and building barriers on contour (stone bunds, planted trees, perennial grasses such as Andropogon and vetiver, shrubs, etc.). In Tominian, both men and women mentioned soil moisture conservation using zai and bunds. Zai is a technique that involves filling small hand-dug holes with manure that are prepared in March or April, and sown just after the first rains. In contrast, male farmers in Dioïla maintain soil moisture during the dry season by tilling and harrowing immediately after the end of the rainy season. To manage soil moisture during the rainy season, farmers in Dioila place stones or grass strips on contour to slow the rate of runoff and increase the downward infiltration of water into the soil profile. To stem the formation of rills, farmers in Tominian place tree branches covered with straw between wooden stakes driven into the soil.

Some farmers also have experience with ratooning. Cassava is ratooned at the beginning of the dry season from November to February. This keeps animals from damaging the crops and also helps the cassava regrow the following season. Women in Tominian ratoon sorghum and millet to gather livestock fodder, however the regrowth must be dried before feeding to animals to avoid poisoning them. ${ }^{5}$

\section{Discussion}

Our case studies offer insight into the complexity of Malian farming systems, especially when approached from the perspective of gendered spaces. They also suggest that a perennial grain crops may very well be a viable option, notwithstanding several important potential limitations highlighted in Figure 7. Clearly, the opinions of farmers with reference to a hypothetical crop that does not yet exist must be qualified as very preliminary indications of socio-ecological suitability. In addition, one of two research team members who was responsible for interviewing male farmers misunderstood how to ask questions on this subject. These data points were removed prior to our interpretation, thus reduced by half the responses from male interviewees on this topic. The remaining data are reliable, and were validated through extended dialog between members of the research team.
We discuss our interviews with Malian farmers in the context of a broad set of perspectives originating from philosophical, anthropological, and agronomic literature. We propose that perennial grains are a viable strategy for an environmentally sound and socially just human-nature relationships in the region. We first make our case on the grounds that perennial grains offer a compelling vision of transforming human relations with nature. We touch on how perennial grains differ from the dominant development models for sub-Saharan Africa. We subsequently discuss the practical implications of perennial grains to integrate into Malian farming systems from the perspectives of agroecology and gendered spaces.

Our literature review and interviews demonstrate several important points about resource sharing of the commons in the customary land use system. Farmers of both genders and pastoralists share lands across space and time. Plots that men manage in any given rainy season produce the majority of agricultural production for family consumption and market. They apply fertilizers and manures to plots, in addition to building soil and water conservation structures. Women grow legumes on relatively more of the plots that they manage than do men in a given season. They use lands that would otherwise be fallowed for crops that tolerate marginal conditions. Women also wild harvest plants and fuelwood from the fallow, or land-extensive phase of the production cycle.

Pastoralism in the dry season still exists in the three regions that we studied. The use of natural resources by these different groups have both degrading and restorative effects on the natural resource base and long-term productivity of the region. Fallows mentioned in our interviews lasted 3-5 years whereas approximately 20 years ago Grigsby (2004) and Grigsby (1996) described fallows lasting 5-10 years. Rural society in Mali is changing, but nevertheless rotations, fallows, nitrogen-fixing legumes, and pastoral land sharing are essential for an equitable and integrated soil fertility management strategy, especially under predicted scenarios of increasing climatic variability.

The ethics of knowledge and resource sharing that embody the non-enclosure, customary land use of West Africa are strikingly similar to the vision for and development of perennial grains followed by the Land Institute. Johnson and Goldstein (2015) argue that the vision of farming systems rooted in perennial 
grains as articulated by Wes Jackson and the Land Institute is an example of post-productivist scientific inquiry and non-enclosing biomimicry. To them it is a collaborative process seeking to learn from the 'more-than-human'. That is, the inspiration for research comes from the complex and resilient prairie ecosystemic interactions instead of isolated elements, as well as local knowledge and the ingenuity of land-based people.

Long term and targeted rehabilitation strategies are needed for the localized and extensive soil degradation in Africa that makes agroecosystems nonresponsive in terms of grain yield even to immediate inputs of synthetic fertilizer (Tittonell \& Giller, 2013). There is in fact a global paradox that human wellbeing is increasing as ecosystem services degrade (MEA, 2005, p. 1; Raudsepp-Hearne et al., 2010). However, the abstraction of human well-being obscures the consequences of sequestering natural resources for a global marketplace that invariably affects the ability of land-based people to sustain their livelihoods (McMichael, 2014). As Johnson and Goldstein (2015) write, 'If we are to craft a different kind of eco-social future, we must consciously shift away from this celebratory - and decidedly humanist - account of innovation's potential and the historical arc of progress.'

The push to increase yields in Africa is currently a primary goal of agricultural development. The transition to agricultural systems that produce more per unit area is based on food insecurity and population growth. Meanwhile, inroads have been made toward the enclosure of the commons, particularly with regard to policy and private sector initiatives around land acquisition and seed privatization (ACB, 2015). We contribute to the debate on agricultural intensification by noting that farming systems of Mali undergo intensification and extensification through space and time. This integration is what sustains sovereignty in terms of ecosystem services, cultural values, diversified and nutritious food, medicine, energy, and family economy. Whether perennial grain agroecosystems ever are realized, our case study offers an alternative to the narrow standard for agricultural development set by high-input, highoutput agriculture. This places perennial grains within the realm of normative visions for future human-nature relations in contrast to intensified annual crop production that is bolstered by a positivist vision of doubling global food production by 2050 (see Tomlinson, 2013).
We stress the importance of shifting to a more holistic set of priorities that include long-term sustainability and equity. Perennial grains deserve serious consideration as a concrete proposal to re-organize the means and social relations of production (Richards, 2009). The vision for perennial grains also coincides with the vision for food sovereignty articulated in Mali by the Nyéléni Declaration (2015). Delegates representing diverse organizations and international movements called on territorial and holistic policies that ensure an inclusive and accountable approach to stewardship. They committed to policies that support women and youth in agroecological food production, as well as ensure customary rights to the commons by farmers and pastoralists. These visions for distributive and procedural justice may also benefit from greater transparency in customary land tenure arrangements (Kuusaana \& Bukari, 2015; Toulmin, Bernstein, Hulme, \& Woodhouse, 2003) and increased integration of the youth in traditional institutions (Rist, Chidambaranathan, Escobar, Wiesmann, \& Zimmermann, 2007).

\section{Specific benefits to women and pastoralists}

Improved soil quality and increased forage resources might be the outcome of breeding a rhizomatous perennial sorghum capable of withstand grazing pressure (personal communication with Stan Cox of the Land Institute). In the context of West Africa, this may be of benefit to women and pastoralists, two groups that often access resources at the margins of agricultural production. We do not wish to imply that perennial grains offer a straight-forward development strategy for all women and pastoralists in the sorghum-producing region of Mali. For example, women farmers mostly grew short duration crops likely to late sowing dates. In addition, farming differed across the sorghum-growing region. We found that women in Tominian farmed grain crops much less compared to Bougouni and Dioilla likely due to both the cultural differences between the Bobo and Bambanan and the more arid conditions in Tominian that did not support rice cultivation. Our observation suggests 'nested and overlapping constituencies' (Rocheleau \& Edmunds, 1997). In fact, knowledge, decision-making, and cultural practices often overlap across genders, as was shown in the management of shea nut parklands in Burkina Faso (Elias, 2015). Carr (2008) writes that feminist post-structural approaches to gender and development reject the idea of a 
universal, generalizable "woman" and argues that gender categories are specific to the place and time in which they are found'. Perennial grains are in their early stage of development and local conditions are a constantly moving target. Therefore, our interpretation is limited to expected traits of perennial grain crops for the general characteristics of farmers and pastoralists in the region. More nuanced studies and ongoing interactions with local communities are needed to further ground crop suitability within local gender, agroecological, and market dynamics.

A clear interest in reducing labour from perennial grains was communicated by interviewees of both genders. Choice experiments carried out concurrently in the same villages showed that improvements in soil quality are highly valued by both genders, while women are particularly interested in saving labour (Waldman and Richardson, submitted). In farming systems with very low levels of mechanization, and relatively low, although growing, population densities labour availability, especially at critical periods like sowing or weeding, are the key bottleneck to increasing food security and the total production of a family (Ollenburger, Descheemaeker, Crane, Sanogo, \& Giller, 2016). This is specifically true for production from women and plots managed by them, and expressed by the fact that external labour is predominantly used for women managed plots (Figure 6), especially for soil cultivation and weeding, but even for sowing. Perennial grain systems may relieve the labour bottleneck for women by reducing the need for soil tillage and the frequency of sowing. There may also be a long-term reduction in weed issues in truly perennial grain systems, especially if the perennial grain crop can establish early in the season with the first rains, and thus compete effectively with mostly annual weeds.

Our interviews also showed that women value saving the cost for or effort to procure seeds. While sorghum does not require a high seed rate, women usually procure sorghum seed from their husbands, unless they save seeds at harvest, and keep it safe for the next sowing season (Siart, 2008). For rice, groundnuts and cowpeas, seed requirements are much higher, and thus a significant cost of production, and often associated with the insecurity of keeping the seed quality throughout the dry season, or finding the appropriate variety and seed in the local markets. The fact that women need to spend effort to source the right seed in itself is actually a factor contributing to delayed sowing, and thus to lower productivity. In addition, women's plots get sown only once men's plots are prepared for sowing (Burton \& White, 1984). Reducing this cost, burden and delays, at least partially, especially for rice, or the legume crops would have significant advantages for women farmers. To achieve this advantage, the perennial crop would have to be able to survive the dry season at predictable rates over at least 2-3 years. While soil and water conditions clearly matter, according to our observations with introduced perennial sorghum, derived from crosses with Sorghum halepense (Paterson et al, submitted), biotic constraints, especially termites also play an important role, especially for woody species like perennial pigeonpea . It is however clear that genetic differences for survival for rhizomes exist for sorghum and are being studied in detail (Paterson et al., submitted). Genetic differences for perenniality of pigeon pea clearly exist as well, although its genetics have not been studied.

Increasing food availability throughout the year seems much more important to women than men, when reflecting on possible advantages of perennial sorghum or other crops. This may extend from the women's disproportionate involvement with food preparation and child care. As Van de Broek (2009) indicated, sorghum grain produced by the women themselves, serves food needs, especially of children, but also other needy members of the household, in times of food shortages. Thus providing an opportunity for improving her own grain availability, with less labour is seen as a critical advantage by women farmers. Developing perennial sorghum or rice to meet these needs, more efficiently than annual varieties, requires direct collaboration with women farmers, working under the production conditions they have access, as the issues to be addressed are complex, and new opportunities may arise, as the breeding progresses. Perennial grains could be developed so that they mature before and/or after annual varieties, thus helping families meet their food needs during times of shortage and inclement weather. Attention is especially needed for insect pests, such as the sorghum midge (Contarinia sorghicola [Coquillett]).

The potential soil improving characteristics of perennial crops are particularly important for family farming in many parts of Mali. Women farmers either usher the least fertile drylands into a fallow or recuperate their fertility for use as male plots, thus serving family needs. Legumes are grown by all women interviewees, often intercropped with cereals. Turning the 
intercropped cereal into a perennial could contribute significantly to soil conservation, as well as improving soil fertility. It would, however, be critical to evaluate the effect of the early regrowth of the perennial cereal crop on the intercropped legume, especially groundnut, the women's main crop. Similarly the harvest of groundnuts could actually be detrimental to the rhizomes of intercropped perennial sorghum.

Perennial grains improve soil quality (Culman et al., 2013), which is especially important for marginal plots cultivated by women and for fallows. Extensive root systems of perennial grains explore deeper soil horizons and thus contribute to the more efficient use of nutrients by crops and the lifting of soil moisture to the root zone (Prieto, Armas, \& Pugnaire, 2012; Sekiya \& Yano, 2004). The reduced tillage of soils means that soil organic matter will increase, which improves the aggregate structure of soils and the potential for the exchange of nutrients. Additionally, perennial legume species like those used in agroforestry and intercropped systems fix important levels of atmospheric nitrogen (Garrity et al., 2010; Mhango, Snapp, \& Phiri, 2013).

Fallows should not be overlooked as a fertility management strategy in West Africa. Women access fallows for cultivating their crops and for wild harvesting, which could include perennial cereal crops, like sorghum. Perennial crops may function as an improved fallow. Although pigeon pea is not easily compatible with open grazing, recent selection efforts highlight the potential to develop perennial grains for fodder or fuelwood production (Orr, Kambombo, Roth, Harris, \& Doyle, 2015).

In addition to women farmers, perennial grains may benefit livestock herders and pastoralists by improving the quality grasslands in the dry season. Our research is limited in this area since we spoke primarily with farmers. However, given the longstanding cultural norms governing land use in West Africa, a perennial grain system would necessarily have to resist grazing pressure or be managed in such a way that minimizes the potential for damage.

\section{Perennial grains for the West African Soudanian Savanna}

Were perennial grain crops to be developed for the sorghum-growing region of Mali, they would need to be targeted for specific agroecological conditions and uses. Perennial sorghum and rice seem to be more promising in the southern Cercles, as dry- season survival depends on water availability during the dry season (Weltzien, field observation). However no testing of any perennial sorghum genotypes has been conducted under conditions resembling those in Tominian cercle. Sorghum and legumes are good candidates for perennial breeding efforts since they already tolerate low-soil fertility, and can survive a long dry season. However, the development of perennial rice is already well advanced, and could thus be put to test in Mali, with farmers' involvement, without additional breeding work initially.

For pigeon pea, a wide range of landrace germplasm is available from India and Southern Africa, including perennials, and could also be tested directly in specific agroecological conditions with interested farmers. However the crop is poorly known by West African farmers and consumers, and thus food processing options would need to be developed at the same time. The advantages of perennial pigeon pea varieties could be their development for flowering at the start of the dry season, when the pressure from the many diverse insect pests is lower. This may, however, cause problems with free-grazing ruminants, from villages or pastoralists, as the crop would occupy the field well into the dry season.

Sorghum is a strong candidate crop for perennial breeding since annual sorghum frequently placed on preferred plots across the three Cercles. Sorghum is grown on soils that retain moisture, especially in the Cercle of Tominian that receives the lowest rainfall levels. Even though in Dioila farmers placed maize on their preferred fields with high fertility and soil moisture, they also reported intercropping sorghum in maize fields so that the sorghum would also benefit from fertilizer subsidies.

As a well-known crop in Mali and West Africa with perenniality traits and an increasingly well understood genetics, sorghum is well suited for breeding programmes. However, significant breeding effort will be required, since existing perennial sorghum material is being developed for extremely different climatic and agroecological conditions - central Kansas in the USA. However the experiences, and insights into the genetics of the traits related to perenniality will be useful. Advantages for breeding perennial sorghum for Mali, or other areas in West Africa will be that the open, loose panicle of the existing perennial sorghum lines derived from crosses with $S$. halepense are the preferred panicle type for West African farmers. However, shattering needs to be reduced and grain size increased. The main challenge - 
physiologically interesting aspect - will be that perenniality will have to be combined with specific expressions of photoperiod sensitivity to ensure that farmers obtain a harvest less threatened by birds, insects, or grazing animals.

In Bougouni and Dioila, rice is grown on seasonally flooded plots. These plots retain soil moisture for the longest period of time into the dry season, which is an important attribute for perennial grains to survive. Some lowlands in the southern Cercle of Bougouni retain soil moisture year-round, while those in the northern Cercle of Tominian retain soil moisture on the order of weeks following a rainfall event. Perennial rice breeding is in an advanced stage of development in China (Sacks, 2014; Zhang et al., 2014). A perennial variety selected for flooded conditions is a likely candidate crop for the region, although clearly requiring further research and development.

\section{Conclusions}

Our study shows that there is an interest in perennial grains in the sorghum-growing region of Mali and that the socio-ecological conditions of customary tenure would support them. There is also a historic precedent in Africa more generally for the use of multi-use grasslands. What is needed are investments to develop the promising germplasm to achieve viable crop types. These include rice, sorghum, and pigeon pea as high priority, and could include pearl millet and cowpea among others. Breeding efforts of perennial crops should consider the complexity of West African farming systems by studying them from an agroecological perspective and co-developing varieties that meet the needs of women farmers and pastoralists. Our research indicates that in sorghum-producing regions of Mali, perennial grains have the greatest chance of succeeding on marginal drylands and seasonally flooded lands that are most often used by women during the rainy season. It is important to recognize important contributions of groups that occupy marginal spaces within complex social dynamics to achieve food security, greater equality, and justice.

\section{Notes}

1. Throughout this manuscript, we refer to the sorghumgrowing region of Mali as 'the region', fully aware that in other contexts the region may refer to West Africa or administrative units within Mali.
2. A Cercle is a second level administrative unit in Mali named after its major city. In Bougouni, we visited the villages of Madina, Niaraka, Dièba, Djadoubala, Sibirila, and Flola. In Dioila, we visited the villages of N'Domi, Fadabougou, Djondougou, Tula, Tiendo, and Zeta. In Tominian, we visited the villages of Seoulasso, Sokoro, Kagnan, Diaga, Minso, and Hasso.

3. Net primary productivity is a vegetation metric that measures the amount of light energy that can be converted directly into plant biomass (Heinsch et al., 2003).

4. Note that we did not collect demographic information from interviewees about people that helped them farm. Therefore, the classification of youth refers to people from a younger generation, such as child, niece, or nephew.

5. Poisoning is likely due to biochemical properties of ratooned sorghum and millet, such as high-cyanide content.

\section{Acknowledgements}

We express our gratitude to the Malian farmers who graciously welcomed us, as well as to various individuals at ICRISAT - Mali and IER - ECOFIL who offered us logistical assistance in the field.

\section{Disclosure statement}

No potential conflict of interest was reported by the authors.

\section{Funding}

This work was supported by Bill and Melinda Gates Foundation [grant number OPP1076311].

\section{ORCID}

Paul Rogé (D) http://orcid.org/0000-0003-2298-5958

\section{References}

ACB. (2015). The expansion of the commercial seed sector in SubSaharan Africa: Major players, key issues and trends. Johannesburg: African Centre for Biodiversity. Retrieved from http://acbio.org.za/the-expansion-of-the-commercialseed-sector-in-sub-saharan-africa-major-players-key-issuesand-trends/

Adebiyi, J., Schmitt Olabisi, L., \& Snapp, S. (2015). Understanding perennial wheat adoption as a transformative technology: Evidence from the literature and farmers. Renewable Agriculture and Food Systems, 1-10. doi:10.1017/ S1742170515000150.

Armstrong, O. N., Glover, D., Reganold, J. P., \& Cox, C. M. (2010). Plant perennials to save Africa's soils. Issues in Science and Technology, 489, 8-10.

Bassett, T. J., \& Zuéli, K. B. (2000). Environmental discourses and the Ivorian Savanna. Annals of the Association of American Geographers, 90(1), 67-95. doi:10.1111/0004-5608.00184

Batello, C., Marzot, M., Touré, A. H., \& Kenmore, P. E. (2004). Kreb. In The future is an ancient lake: Traditional knowledge, 
biodiversity and genetic resources for food and agriculture in lake Chad Basin ecosystems (pp. 105-125). Rome: FAO.

Batterbury, S., \& Forsyth, T. (1999). Fighting back: Human adaptations in marginal environments. Environment, 41(6), 6-9. doi:10.1080/00139159909604639

Bernard, H. R. (2011). Research methods in anthropology: Qualitative and quantitative approaches (5th ed.). Lanham: AltaMira Press.

Boserup, E. (1971). Women's role in economic development. London: Unwin.

Bourdieu, P. (1992). The practice of reflexive sociology. In P. Bourdieu \& L. D. Wacquant (Eds.), An invitation to reflexive sociology (pp. 216-260). Chicago: University of Chicago Press.

Brottem, L., Turner, M. D., Butt, B., \& Singh, A. (2014). Biophysical variability and pastoral rights to resources: West African transhumance revisited. Human Ecology, 42(3), 351-365. doi:10. 1007/s10745-014-9640-1

Burton, M. L., \& White, D. R. (1984). Sexual division of labor in agriculture. American Anthropologist, 86(3), 568-583.

Busson, F. (1965). Plantes Alimentaires de L'ouest Africain: Étude Botanique, Biologique et Chimique, Avec La Collaboration Technique de P. Jaeger, P. Lunven et M. Pinta. Marseille: L'Imprimerie LeConte.

Carr, E. R. (2008). Men's crops and women's crops: The importance of gender to the understanding of agricultural and development outcomes in Ghana's central region. World Development, 36(5), 900-915. doi:10.1016/j.worlddev.2007. 05.009

CEPIA, IER, and CIRAD. (2007). Dimensions Structurelles de La Libéralisation Pour L'agriculture et Le Développement Rural. Phase I. World Bank. Retrieved from http://web.worldbank. org/

CEPIA, IER, and CIRAD. (2008). Changements Structurels Des économies Rurales Dans La Mondialisation. Phase II. World Bank. Retrieved from http://web.worldbank.org/

Cox, T. S., Bender, M., Picone, C., Van Tassel, D. L., Holland, J. B., Brummer, E. C., ... Jackson, W. (2002). Breeding perennial grain crops. Critical Reviews in Plant Sciences, 21(2), 59-91. doi:10.1080/0735-260291044188

Cox, T. S., Glover, J. D., Tassel, D. L. V., Cox, C. M., \& DeHaan, L. R. (2006). Prospects for developing perennial grain crops. BioScience, 56(8), 649-659. doi:10.1641/0006-3568(2006)56 [649:PFDPGC]2.0.CO;2

Cox, T. S., Picone, C., \& Jackson, W. (2004). Research priorities in natural systems agriculture. Journal of Crop Improvement, 12 (1), 511-531. doi:10.1300/J411v12n01_10

Creevey, L. (1987). Family farms and improved development assistance for rural women in Mali. In Discovering the African past: Essays in honor of Daniel F. Mccall (pp. 131-148). Papers on Africa 8. Boston: Boston University.

Creevey, L. E. (1986). The role of women in agriculture in Mali. In L.E. Creevey (Ed.), Women farmers in Africa (pp. 51-66). Syracuse: Syracuse University Press.

Crews, T. E., \& DeHaan, L. R. (2015). The strong perennial vision: A response. Agroecology and Sustainable Food Systems, 39(5), 500-515. doi:10.1080/21683565.2015.1008777

Culman, S. W., Snapp, S. S., Ollenburger, M., Basso, B., \& DeHaan, L. R. (2013). Soil and water quality rapidly responds to the perennial grain Kernza wheatgrass. Agronomy Journal, 105(3), 735-744. doi:10.2134/agronj2012.0273
Dalziel, J. M. (1985). The useful plants of west tropical Africa (2nd ed.). Kew: Royal Botanic Gardens.

de Vries, P., \& Djitèye, F. W. T. (1982). La Productivité Des Pâturages Sahéliens: Une étude Des Sols, Des Végétations et de L'exploitation de Cette Ressource Naturelle. Agricultural Research Reports 918. Wageningen: Centre for Agricultural Publication; Documentation.

Denham, D. (1985). Narrative of travels and discoveries in Northern and Central Africa, in the years 1822, 1823, and 1824, extending across the great desert to the tenth degree of Northern Latitude, and from Kouka in Bornou, to Sackatoo, the capital of the Felatah empire. London: Darf.

Djurfeldt, G. (1996). Defining and operationalizing family farming from a sociological perspective. Sociologia Ruralis, 36(3), 340351. doi:10.1111/j.1467-9523.1996.tb00026.x

Elias, M. (2015, April). Gender, knowledge-sharing and management of shea (Vitellaria paradoxa) parklands in central-west Burkina Faso. Journal of Rural Studies, 38, 27-38. doi:10. 1016/j.jrurstud.2015.01.006

ESRI. (2014). Arcmap 10.0-10.2. Redlands: Environmental Systems Research Institute.

Feyerabend, P. (2010). Against method (4th ed.). New York, NY: Verso.

Garrity, D. P., Akinnifesi, F. K., Ajayi, O. C., Weldesemayat, S. G., Mowo, J. G., Kalinganire, A., ... Bayala, J. (2010). Evergreen agriculture: A robust approach to sustainable food security in Africa. Food Security, 2(3), 197-214. doi:10.1007/s12571010-0070-7

Glover, J. D., Culman, S. W., DuPont, S. T., Broussard, W., Young, L., Mangan, M. E., Mai, J. G., et al. (2010). Harvested perennial grasslands provide ecological benchmarks for agricultural sustainability. Agriculture, Ecosystems \& Environment, 137(1), 3-12. doi:10.1016/j.agee.2009.11.001

Glover, J. D. (2005). The necessity and possibility of perennial grain production systems. Renewable Agriculture and Food Systems, 20(1), 1-4. doi:10.1079/RAF200499

Grigsby, W. J. (1996). Women, descent, and tenure succession among the Bambara of West Africa: A changing landscape. Human Organization, 55(1), 93-98.

Grigsby, W. J. (2004). The gendered nature of subsistence and its effect on customary land tenure. Society \& Natural Resources, 17(3), 207-222. doi:10.1080/08941920490270230

GSFC DAAC. (2011). TRMM/TMPA 3B43. Greenbelt: NASA/Goddard Space Flight Center (GSFC). Retrieved from http://mirador.gsfc. nasa.gov/collections/TRMM_3B43_007.shtml

Harlan, J. R. (1989). Wild grass seed harvesting in the Sahara and Sub-Sahara of Africa. In DR Harris, \& GC Hillman (Eds.), Foraging and farming: The evolution of plant exploitation (pp. 79-98). London: Unwin Hyman.

Heinsch, F. A., Reeves, M., Votava, P., Kang, S., Milesi, C., Zhao, M., Glassy, J., et al. (2003). MOD17A2/A3. Mod17 User's Guide, 1-57. Retrieved from http://www.ntsg.umt.edu/modis/

Hounkonnou, D., Kossou, D., Kuyper, T. W., Leeuwis, C. Nederlof, E. S., Röling, N., ... van Huis, A. (2012, April). An innovation systems approach to institutional change: Smallholder development in West Africa. Agricultural Systems, 108, 74-83. doi:10.1016/j.agsy.2012.01.007

Inkscape. (2015). Accessed December 6. Retrieved from https:// inkscape.org/en/

ISRIC. (2013). Soil property maps of Africa at $1 \mathrm{Km}$. Retrieved from http://www.isric.org 
Jackson, W. (1980). New roots for agriculture. San Francisco: Friends of the Earth.

Jackson, W. (2002). Natural systems agriculture: A truly radical alternative. Agriculture, Ecosystems \& Environment, 88(2), 111-117. doi:10.1016/S0167-8809(01)00247-X

Johnson, E. R., \& Goldstein, J. (2015). Biomimetic futures: Life, death, and the enclosure of a more-than-human intellect. Annals of the Association of American Geographers, 105(2), 387-396. doi:10.1080/00045608.2014.985625

Kuusaana, E. D., \& Bukari, K. N. (2015, December). Land conflicts between smallholders and Fulani pastoralists in Ghana: Evidence from the Asante Akim North district (AAND). Journal of Rural Studies, 42, 52-62. doi:10.1016/j.jrurstud. 2015.09.009

Larder, N. (2015). Space for pluralism? Examining the Malibya land grab. The Journal of Peasant Studies, 42(3), 839-858. doi:10.1080/03066150.2015.1029461

Le Houérou, H. N. (1989). The grazing land ecosystems of the African Sahel. Ecological Studies 75. New York, NY: SpringerVerlag.

Loos, J., Abson, D. J., Chappell, M. J., Hanspach, J., Mikulcak, F., Tichit, M., \& Fischer, J. (2014). Putting meaning back into 'sustainable intensification'. Frontiers in Ecology and the Environment, 12(6), 356-361. doi:10.1890/130157

LP DAAC. (2000a). MODIS land surface temperature (MOD11A2). Sioux Falls: USGS Earth Resources Observation and Science (EROS) Center. Retrieved from https://lpdaac.usgs.gov/ dataset_discovery/modis/modis_products_table/mod11a2

LP DAAC. (2000b). MODIS net primary productivity (MOD17A3). Sioux Falls, South Dakota: USGS Earth Resources Observation and Science (EROS) Center. Retrieved from https://lpdaac. usgs.gov/dataset_discovery/modis/modis_products_table/mod $17 a 3$

McMichael, P. (2014). Rethinking land grab ontology. Rural Sociology, 79(1), 34-55. doi:10.1111/ruso.12021

MEA. (2005). Ecosystems and human well-being: Current state and trends. Retrieved from http://www.millenniumassessment. org/en/index.aspx

Méndez, V. E., Bacon, C. M., \& Cohen, R. 2013. Agroecology as a transdisciplinary, participatory, and action-oriented approach. Agroecology and Sustainable Food Systems 37 (1): 3-18. doi:10. 1080/10440046.2012.736926

Mhango, W. G., Snapp, S. S., \& Phiri, G. Y. K. (2013). Opportunities and constraints to legume diversification for sustainable maize production on smallholder farms in Malawi. Renewable Agriculture and Food Systems, 28(3), 234-244. doi:10.1017/S1742170512000178

Moore, H. L., \& Vaughan, M. (1994). Cutting down trees: Gender, nutrition, and agricultural change in the Northern province of Zambia, 1890-1990. Portsmouth: Heinemann.

Nachtigal, G. (1971). Sahara and Sudan. London: C. Hurst.

Neuwirth, E. (2011). RColorbrewer: ColorBrewer palettes.

NRC. (1996). Lost crops of Africa: Grains. Vol. 1. 3 vols. Washington, DC: National Academy.

Nyéléni Declaration. (2015). Declaration of the international forum for agroecology. Sélingué: International Forum for Agroecology. Retrieved from http://www.foodsovereignty. org/forum-agroecology-nyeleni-2015/

Ollenburger, M. H., Descheemaeker, K., Crane, T. A., Sanogo, O. M., \& Giller, K. E. (2016, October). Waking the sleeping giant: Agricultural intensification, extensification or stagnation in
Mali's Guinea Savannah. Agricultural Systems, 148, 58-70. doi:10.1016/j.agsy.2016.07.003

Orr, A., Kambombo, B., Roth, C., Harris, D., \& Doyle, V. (2015). Adoption of integrated food-energy systems: Improved cookstoves and pigeonpea in Southern Malawi. Experimental Agriculture, 51(2), 191-209. 10.1017/S0014479714000222

Paterson, A. H., Kong, W. , Johnston, R. M., Nabukalu, P., Wu, G., \& Poehlman, W., ... Scanlon, M. J. (submitted). The evolution of an invasive plant, Sorghum halepense L. ('Johnsongrass'). Science.

Prieto, I., Armas, C., \& Pugnaire, F. I. (2012). Hydraulic lift promotes selective root foraging in nutrient-rich soil patches. Functional Plant Biology, 39(9), 804-812. doi:10.1071/FP12070

Raudsepp-Hearne, C., Peterson, G. D., Tengö, M., Bennett, E. M., Holland, T., Benessaiah, K.,... Pfeifer, L. (2010). Untangling the environmentalist's paradox: Why is human well-being increasing as ecosystem services degrade? BioScience, 60(8), 576-589. doi:10.1525/bio.2010.60.8.4

R Core Team. (2013). R: A language and environment for statistical computing. Vienna: R Foundation for Statistical Computing.

Richards, D. G. (2009). Economics and 'nature's standard': Wes Jackson and The land institute. Review of Radical Political Economics, 41(2), 186-195. doi:10.1177/0486613409331424

Rist, S., Chidambaranathan, M., Escobar, C., Wiesmann, U., \& Zimmermann, A. (2007). Moving from sustainable management to sustainable governance of natural resources: The role of social learning processes in rural India, Bolivia and Mali. Journal of Rural Studies, 23(1), 23-37. doi:10.1016/j. jrurstud.2006.02.006

Rocheleau, D., \& Edmunds, D. (1997). Women, men and trees: Gender, power and property in forest and agrarian landscapes. World Development, 25(8), 1351-1371. doi:10.1016/ S0305-750X(97)00036-3

Runge, C. F. (1986). Common property and collective action in economic development. World Development, 14(5), 623-635. doi:10.1016/0305-750X(86)90128-2

Sacks, E. J. (2014). Perennial rice: Challenges and opportunities. In C. Batello, L. J. Wade, N. Pogna, A. Bozzini, \& J. Choptiany (Eds.), Perennial crops for food security (pp. 1626). Rome: FAO.

Schnell, R. (1957). Plantes Alimentaires et Vie Agricole de L'Afrique Noire; Essai de Phytogéographie Alimentaire. Paris: Éditions Larose.

Sekiya, N., \& Yano, K. (2004). Do pigeon Pea and Sesbania supply groundwater to intercropped maize through hydraulic lift? Hydrogen stable isotope investigation of xylem waters. Field Crops Research, 86(2), 167-173. doi:10.1016/j.fcr.2003.08.007

Siart, S. (2008). 'Strengthening local seed systems: Options for enhancing diffusion of varietal diversity of Sorghum in southern Mali.' Series communication and extension 85. Weikersheim: Margraf.

Simons, H. (2009). Case study research in practice. Los Angeles: SAGE.

Struik, P. C., Kuyper, T. W., Brussaard, L., \& Leeuwis, C. (2014). Deconstructing and unpacking scientific controversies in intensification and sustainability: Why the tensions in concepts and values? Current Opinion in Environmental Sustainability, SI: Sustainability Governance and Transformation, 8, 80-88. doi:10.1016/j.cosust.2014.10.002

Svensson, L., \& Doumas, K. (2013). Contextual and analytic qualities of research methods exemplified in research on teaching. 
Qualitative Inquiry, 19(6), 441-450. doi:10.1177/1077800413 482097

Thébaud, B., \& Batterbury, S. (2001). Sahel pastoralists: Opportunism, struggle, conflict and negotiation. Global Environmental Change, 11(1), 69-78. doi:10.1016/S0959-3780 (00)00046-7

Thiam, M. (1986). The role of women in rural development in the Segou Region of Mali. In L. E. Creevey (Ed.), Women farmers in Africa (pp. 51-66). Syracuse: Syracuse University Press.

Thomas, G. (2011). A typology for the case study in social science following a review of definition, discourse, and structure. Qualitative Inquiry, 17(6), 511-521. doi:10.1177/ 1077800411409884

Tittonell, P., \& Giller, K. E. (2013). When yield gaps are poverty traps: The paradigm of ecological intensification in African smallholder agriculture. Field Crops Research, 143, 76-90. doi:10.1016/j.fcr.2012.10.007

Tomlinson, I. (2013, January). Doubling food production to feed the 9 billion: A critical perspective on a key discourse of food security in the UK. Journal of Rural Studies, Food Security, 29, 81-90. doi:10.1016/j.jrurstud.2011.09.001

Toulmin, C., Bernstein, H., Hulme, D., \& Woodhouse, P. (2003). African enclosures? The social dynamics of wetlands in drylands. Africa: Journal of the International African Institute, 73 (1), 141. doi:10.2307/3556882

Trapnell, C. G. (1953). The soils, vegetation, and agriculture of North-Eastern Rhodesia. Lusaka: Government Printer.
Van de Broek, E. (2009). Gender in development thinking: The case study of ICRISAT's development initiatives for female sorghum producers in Mali (MSc. thesis). Rural Development Sociology, Wageningen UR.

van Dusen Lewis, J. (1978). Small farmer credit and the village production unit in rural Mali. African Studies Review, 21(3), 29-48. doi: $10.2307 / 523884$

Wagoner, P. (1990). Perennial grain development: Past efforts and potential for the future. Critical Reviews in Plant Sciences, 9(5), 381-408. doi:10.1080/07352689009382298

Waldman, K. B., \& Richardson, R. B. (submitted). Crop duration and smallholder climate change adaptation in Mali. Environment and Development Economics.

Wickham, H. (2007). Reshaping data with the reshape package. Journal of Statistical Software, 21(12), 1-20.

Wickham, H. (2009). Ggplot2: Elegant graphics for data analysis. Springer.

Wickham, H. (2011). The split-apply-combine strategy for data analysis. Journal of Statistical Software, 40(1), 1-29.

Wooten, S. (2003). Women, men, and market gardens: Gender relations and income generation in rural Mali. Human Organization, 62(2), 166-177.

Zhang, S., Wang, W., Zhang, J., Ting, Z., Huang, W., Xu, P., ... $\mathrm{Hu}, \mathrm{F}$. (2014). The progression of perennial rice breeding and genetics: Research in China. In C. Batello, L. J. Wade, N. Pogna, A. Bozzini, \& J. Choptiany (Eds.), Perennial crops for food security (pp. 27-38). Rome: FAO. 